\title{
The Effect of Capital Adequacy on Returns of Assets of Commercial Banks in Kosovo
}

\author{
Halit Shabani ${ }^{1}$, Fisnik Morina ${ }^{2}$, Valdrin Misiri ${ }^{3}$
}

\begin{abstract}
The purpose of this study is to analyze the effects of capital adequacy on the return of assets to the banking sector in Kosovo. The capital adequacy ratio measures the ability of a financial institution to meet its liabilities by comparing its capital with its assets. As the banking system is one of the strongest points of our country's economy, it is understood that the capital adequacy ratio is used by banks to determine the adequacy of their capital holdings while taking their risk exposures into account.

This study will provide empirical evidence of the relationship between capital adequacy and return on commercial bank assets in Kosovo during 2008-2017. It will be using secondary data obtained from audited reports of domestic banks and reports from the Central Bank of Kosovo. To measure the empirical results during this research, these econometric methods have been used: the linear regression model, the model of the fixed effects, and the random model and the GMM model. Based on the results we can conclude that capital adequacy has a positive impact on asset returns and has a significant relationship. In addition, other factors have had a positive and negative impact on the return of commercial banks' assets in Kosovo.
\end{abstract}

Keywords: capital adequacy, return on assets, loans, deposits, interest rates.

JEL Classification: G21, G31, G32

\section{Introduction}

Capital adequacy ratio (CAR) is the ratio determined by regulatory authority in the banking sector and this ratio can be used to test the health of the banking system. The capital of the bank consists of first and second class capital. First-class capital includes: paid-in capital, undistributed profits, and non-cumulative preference shares. The capital of the second class includes provisions for credit losses, capital market instruments, and subordinated liabilities. Banks are required to maintain a minimum ratio of $12 \%$ of the total capital and $8 \%$ of first-class capital in relation to assets weighted by risk and other risks. Therefore, the ratio of capital adequacy to commercial banks is an important issue that has received considerable attention in financial literature.

Numerous studies by foreign researchers argue that different capital adequacy factors have a positive impact on the banking sector. One of the scholars who argues this is Frederik Ambal Mugwang'a who points the impact of these factors on commercial banks of Kenya. Kwan and Eisenbeis (1995); Hughs (1995) argued that it is necessary to recognize the concept of efficiency in empirical models that link the bank's capital with the risk and distinguish between effective and inefficient risk enterprise. Given that

\footnotetext{
${ }^{1}$ University "Haxhi Zeka" - Peja, Kosovo,

${ }^{2}$ University "Haxhi Zeka" - Peja, Kosovo, (corresponding author)

${ }^{3}$ University "Haxhi Zeka" - Peja, Kosovo
} 
capital adequacy has been a focus for a number of theories and studies, it is considered to show the profitability of each financial institution (Bourke 1989, White and Morrison 2001). There are very few studies in our country that have analyzed the effects of capital adequacy on the performance of the banking sector in Kosovo.

The main objective of this study is to see whether there is a positive or negative impact on capital adequacy in returning assets to the Kosovo banking sector. The variables used in this research are: ROA, CAR, loans, deposits, interest rates on loans, and NPLs because these variables are less widely used by authors and other researchers. This research is made up of the literature review. The remainder shows empirical analysis and research methodology as well as the empirical data derived from the study about capital adequacy and their impact on asset returns and findings of this study.

\section{Review the literature}

Banks play an important role in the economic development of a country, given the relationship between the banking sector wellbeing and economic growth (Rajan and Zingales 1998, Cetorelli and Gambera 2001, Beck and Levine 2004). Knowing that capital adequacy affects the profitability of the financial sector is essential not only for bank managers but also for stakeholders such as the Central Bank, banking associations, governments, and other financial authorities.

There were various arguments in support of capital adequacy. The first argument shows that capital adequacy regulation encourages careful compliance, but the argument has not explained why there is a need to regulate capital adequacy. This brought the second argument, from Ventson \& Keufman 1999, that regulating capital adequacy is a measure to counter the moral hazard problems from regulators. The third and last argument is that the regulation of capital adequacy protects small depositors in banks, as they account for the largest percentage of bank customers.

Capital adequacy has been the focus of a number of theories and studies, as it is considered to be one of the main drivers of profitability of any financial institution. According to Al-Sabbagh (2004), capital adequacy is defined as a measure of exposure to the bank's risk. The risk of banks is classified as credit risk, market risk, and operational risk. Therefore, regulatory authorities have used the capital adequacy ratio as an important measure of "security and stability" for banks and deposit institutions because they see capital as a tool for absorbing losses.

According to Kishore (2005), capital adequacy is a minimum fund that a financial institution should have to run its business in a more economical and prudent manner in order to be able to meet depositors' demands for their money. With capital adequacy, banks will be able to meet their requirements and at the same time have sufficient liquidity to maintain their asset base.

Pandey (2005), in his argument, states that adequate capital is a regulated amount of the capital base used by the banking industries to effectively perform the primary function by preventing failure through absorbing losses. On the contrary, there are theories that argue that in a world of perfect financial markets, the capital structure and, consequently, the regulation of capital is insignificant (Modiglian and Miller, 1958). 
In 1999, Demirguc-Kunt and Huizinga analyzed the capital adequacy effects on banking sector performance in 80 countries for the period 1988-1995. They concluded that capital adequacy has had a positive impact on asset return (ROA). Kaya (2002) also found that the ratio of capital adequacy has had a positive impact on ROA and a negative impact on ROE. In addition, Abreu and Mendes (2002) analyzed the banks of Spain, France, Portugal, and Germany for the period 1986-1999 and concluded that they had a positive impact on capital adequacy ratios both in ROA and ROE.

Another very important study about the financial reports affecting the profitability of the bank was carried out by Haslem (1969) who collected the balance and income statement of all banks that were members of the US Federal Reserve System. His study showed that most of the financial reports have significant bonds with profitability, particularly the ratio of capital adequacy, interest expense, bank size, and loan size. Concerning this, Wall (1985) concluded that the bank deposit ratio also has a significant effect on the profitability of banks.

To see if the capital adequacy ratio affects the return of Kosovo's banking sector assets, some studies have been conducted in this regard. Author Durguti (2015) conducted an empirical analysis by throwing some hypotheses on the influencing elements in the capital adequacy ratio in the banking sector. In the first hypothesis, this author concludes that ROA has a positive impact on increasing the capital adequacy ratio according to Basel's requirements. Also in his study, it appears that the capital adequacy ratio is positive as in the study (Kandil and Nauxer in 2007), which proves that if banks raise their share capital, they can withstand more exposure to risk.

The authors' findings (Groop and Heider, 2007) have argued that profit-making banks tend to have more capital in relation to assets. Therefore, it is natural to have a positive relationship between return on assets (ROA) and capital adequacy ratio (CAR).

In general, a number of studies have shown various factors affecting banks' capital adequacy, but in Kosovo, not many studies have been conducted with regard to capital adequacy and its impact on asset return (ROA). This research aims to demonstrate an empirical model to see whether capital adequacy has an impact on the return of the banking sector of Kosovo.

\section{Econometric analysis and specification of the econometric model}

For carrying out econometric analysis of this study, 7 commercial banks operating in the Kosovo banking system are included in the study. This study includes banks: Procredit Bank, Raiffeisen Bank, NLB Prishtina, TEB, BKT, BPB and Economic Bank where data were collected over a period of 10 years, from 2008 to 2017. The data collection was made by audited reports of each bank and the Central Bank of Kosovo. The specification of the GMM model to test the impact of CAR in ROA in the Kosovo banking sector is:

$R O A_{i, t}=B_{0}+B_{1} C_{A R_{i, t}}+B_{2} L_{O A N S} i, t+B_{3}$ DEPOSITS $_{i, t}+B_{4} \operatorname{IRL}_{i, t}+B_{5} N_{P L} L_{i, t}+u_{i, t}$

As a dependent variable, we have determined ROA, or return on assets, is an indicator that expresses how profitable a company is to its total assets. Several studies by different 
authors have used the linear regression model in their research to measure the relationship between the internal factors and the performance of banks. The findings of these studies showed that ROA is directly affected by CAR or the capital adequacy ratio which has a significant negative relationshi. CAR in our research is taken as an independent variable that is a measure of bank capital expressed as a percentage of exposures of the credit risk of the bank.

As a second independent variable, the loan, (Christin Zhang and Liyun Dong) in their research showed that the loans have a positive impact on ROA. Also, according to Abre and Mendes (2000), loans represent one of the highest assets that yield high rates of return, and the more banks offer loans, the more they generate income and more profit. However, we should be aware that if bank loans are not high, more deposits may decrease profits and may result in low profitability for banks.

The study conducted by Tunay and Silpar (2006) on the profitability of the Turkish banking sector found that the deposit ratio had a negative impact on ROA. The impact of non-performing loans (NPLs) on ROA is mainly negative. NPLs, in almost every country, have an average of $11 \%-15 \%$. However, due to the lack of reports of some banks for non-performing loans, it can be understood that the NPL problem is greater than the published official statistics. Regarding the impact of NPL on ROA, according to the study conducted by Kaya (2002), nonperforming credits are adversely affected by ROA.

For testing these variables we have used some models such as: linear regression model, fixed effect model, random effects model, and GMM. The results that will be interpreted are those of the GMM model.

The hypotheses set out in this study are:

- Hypothesis (H1): Capital adequacy has a positive impact on the return on assets

- $\quad H y p o t h e s i s(H 2):$ Loans positively affect asset return

- $\quad H y p o t h e s i s(H 3):$ Deposits negatively affect asset return

- $\quad$ Hypothesis (H4): Interest rates on loans positively affect asset return

- $\quad H y p o t h e s i s$ (H5): Non-performing loans negatively affect asset return

Tab.1- ROA \& CAR at commercial banks of Kosovo during the period 2008-2017

\begin{tabular}{|l|l|l|l|l|l|l|l|l|l|l|}
\hline $\begin{array}{l}\text { Banking sector of } \\
\text { Kosovo }\end{array}$ & $\mathbf{2 0 0 8}$ & $\mathbf{2 0 0 9}$ & $\mathbf{2 0 1 0}$ & $\mathbf{2 0 1 1}$ & $\mathbf{2 0 1 2}$ & $\mathbf{2 0 1 3}$ & $\mathbf{2 0 1 4}$ & $\mathbf{2 0 1 5}$ & $\mathbf{2 0 1 6}$ & $\mathbf{2 0 1 7}$ \\
\hline ROA & 3 & 1.5 & 1.8 & 1.7 & 0.8 & 1 & 2.2 & 2.5 & 2.6 & 2.6 \\
\hline CAR & 16.5 & 18.1 & 18.7 & 17.2 & 17.2 & 15 & 17.4 & 19 & 18.7 & 18.1 \\
\hline
\end{tabular}

Source: Data Processing by Authors

Table 1 shows the return on assets and capital adequacy of Kosovo's banking sector for the period 2008-2017. 


\section{RETURN ON ASSETS AND CAPITAL ADEQUACY}

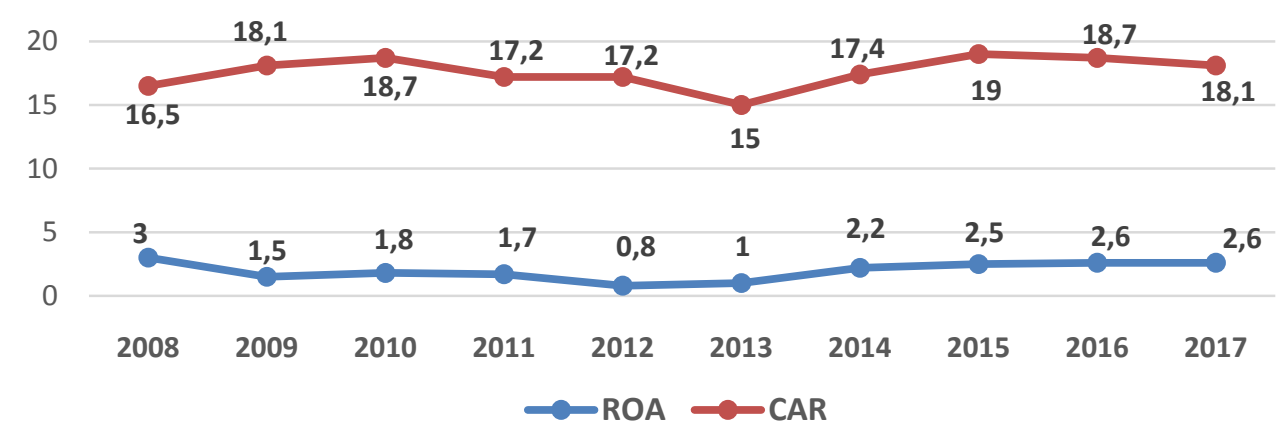

Fig.1. Return on assets and capital adequacy of the banking sector 2008-2017

Source: Data Processing by Authors

In addition to the tabular form, ROA and CAR of the Kosovo banking sector is also presented graphically. The return on assets as seen in the graph from year to year had a continuous increase and decrease. In 2008, the banking sector had the return on assets of $3 \%$; in 2009, this rate was lowered to $1.5 \%$; in 2010 and 2011, if compared to 2009, ROA increased; but again in 2012, the return on assets decreased by 0.8\%; from 2014 to 2017 the ROA has continued to grow; and in 2016 and 2017 the return on assets remained the same at $2.6 \%$.

Regarding the capital adequacy shown in the figure, it is noted that Kosovo's banking sector is well capitalized. In 2008, CAR was $16.5 \%$, which is considered to be a low ratio if we compare it to other years until 2013 where CAR falls to $15 \%$; but it is above the limit required by CBK. In 2014, this rate increased to $17.4 \%$; 2015 was the year with a capital adequacy ratio of at most 19\%; while 2016 and 2017 had lower CARs at 18.7\% and $18.1 \%$. Banks have consistently maintained the capital adequacy ratio at a higher level in relation to the minimum requirements set by the CBK.

\section{Econometric results and findings of the study}

The econometric results presented in the table below are used to analyze the effect of capital adequacy (CAR) on return on assets (ROA). This study uses regression analysis with OLS econometric technique presented in the equation above to make data analysis and empirically verifies whether there is an important relationship between dependent ROA variables and independent variables such as CAR, loans, deposits, interest rates on loans, and NPLs. Interpretation of the results is done with the GMM model. 
Table 2: Results of regression models

\begin{tabular}{|l|l|l|l|c|}
\hline Variables & $\begin{array}{l}\text { LINEAR } \\
\text { REGRESION } \\
\text { MODEL }\end{array}$ & $\begin{array}{l}\text { FIXED } \\
\text { EFFECT } \\
\text { MODEL }\end{array}$ & $\begin{array}{l}\text { RANDOM } \\
\text { EFFECT } \\
\text { MODEL (GLS) }\end{array}$ & $\begin{array}{l}\text { GMM } \\
\text { MODEL }\end{array}$ \\
\hline $\begin{array}{l}\text { Return on Assets } \\
\text { (ROA) }\end{array}$ & - & - & - & $0.3616^{* * *}$ \\
\hline $\begin{array}{l}\text { Capital Adequacy } \\
\text { (CAR) }\end{array}$ & $0.1762^{* * *}$ & $-0.0612^{* * *}$ & $0.0855^{* * *}$ & $0.0165^{* * *}$ \\
\hline Loans & $(0.000)$ & $(0.000)$ & $(0.001)$ & $(0.000)$ \\
\hline Deposits & $\begin{array}{l}3.3628^{* * *} \\
(0.009)\end{array}$ & $\begin{array}{l}2.8588^{* * *} \\
(0.016)\end{array}$ & $\begin{array}{l}3.6906^{* * *} \\
(0.064)\end{array}$ & $3.6771^{* * *}$ \\
& $-3.4303^{* * *}$ & $-2.4288^{* * *}$ & $-3.9133^{* * *}$ & $(0.001)$ \\
\hline Interest rates on & $(0.099)$ & $(0.222)$ & $(0.048)$ & $-3.824)^{* * *}$ \\
loans & $0.2065^{* * *}$ & $0.2531^{* * *}$ & $0.2501^{* * *}$ & $0.000)$ \\
\hline $\begin{array}{l}\text { Non-performing } \\
\text { loans (NPL) }\end{array}$ & $(0.000)$ & $(0.000)$ & $(0.000)$ & $(0.000)$ \\
\hline
\end{tabular}

Source: Authors' calculations

Empirical results in table in the GMM model show that capital adequacy (CAR) has a positive impact on the return of banks' assets and also has a significant relationship. This positive outcome is related to Shiang Liu's studies that show that in the banking sector, CAR has a positive impact on ROA, but contradicts the results of the research by Kamande (2016) that says CAR has a negative impact on ROA.

As seen from the table of econometric results, the loans positively affect the return on assets. An increase in loans of 1\% will increase the 3.6\% return on assets. As much as the bank issues the loan, the more it generates income, the higher the profit will be. The third independent variable are deposits, which have a negative impact on the return of these banks' assets. If deposits increase by $1 \%$ then this will affect the $-3.8 \%$ reduction in asset returns, a result associated with the study by researchers Tunay and Silpar who stated that deposits negatively impact the return of banks' assets.

Based on this analysis we can see that interest rates on loans have a significant relaitonship and have a positive impact on asset return (ROA). An increase of 1\% of interest rates on loans will cause the return on assets to increase by $0.16 \%$. Nonperforming loans (NPLs) as shown in the table represent a significant relationship and appear to have a negative impact on the return on bank assets, i.e., an increase of $1 \%$ will impact the decline in ROA of $0.10 \%$; the result of which corresponds with the fact that NPLs negatively affect banks because they are at risk of not paying these loans, which also affects the bank's profitability.

Based on these empirical results, capital adequacy has a positive impact on the return of bank assets and there is a significant relationship between these two variables. This report is used to protect depositors and to promote the stability and efficiency of the financial system. The reason why CAR's minimum ratios are critical is to ensure that banks have enough mitigation to absorb a reasonable amount of losses before they become unable to pay and consequently lose depositors' funds. Capital adequacy ratios ensure the efficiency and stability of a country's financial system by reducing the risk of 
banks becoming incapable of paying. The higher the ratio of bank capital adequacy ratio is, the higher the degree of protection money to depositors is.

H1: The capital adequacy ratio has a positive impact on the return on assets. - The results obtained from the econometric models on the first hypothesis set out in this study (that capital adequacy has a positive impact on asset return) is confirmed, since $\mathrm{P}$-value $(\mathrm{P}=0,000)$ is less than 0.05 , which means that the hypothesis is accepted because it is significant.

H2: Loans positively affect asset returns. - Based on the hypothesis, the empirical findings from the GMM model verified the hypothesis. Loans have a positive impact on asset returns, as it has a significant relationship $(\mathrm{P}=0.001)$ that is less than 0.05 and this means that the second hypothesis is accepted.

H3: Deposits negatively affect asset returns. - Since, P-value $(P=0.000)$ is less than 0.05, this means that the third hypothesis is accepted. Deposits negatively affect asset returns.

H4: Interest rates on loans positively affect asset returns. - Based on the econometric results, the validity of the fourth hypothesis is verified as P-value (0.000) and is within the standard level of significance.

H5: Non-performing loans negatively affect asset returns. - The results of the econometric models provide evidence that non-performing loans have adversely affected the performance of commercial banks in Kosovo for the period 2008 - 2017.

\section{Conclusions and recommendations}

In the framework of this study, we have analyzed some theoretical and empirical arguments regarding the capital adequacy and its impact on the return of assets. The empirical results regarding the variables proved to be successful considering the influence of independent variables on the dependent variables, where as a dependent variable was: ROA and independent were: capital adequacy, loans, deposits, interest rates on loans, and loans non-performing (NPL). The data used in this empirical study were obtained from the Audited Reports of Banks in Kosovo and the CBK for the period 2008-2017, which means that 10 years have been included.

Based on the GMM model, we have come up with the following results: out of 5 tested variables, all variables are significant, 3 of them have a positive impact on asset return, and 2 other have a negative impact on asset return. These empirical results appear to be the same, as many studies carried out by other authors have been analyzed in the review of literature. Based on the literature review and the empirical results of the hypotheses outlined in our research, we can conclude that capital adequacy has a positive impact on asset returns.

Since capital adequacy appears to have a positive impact on the return on commercial banks' assets in Kosovo, it is recommended that the Central Bank of Kosovo fully implements capital adequacy regulations based on the Basel and EU Committee Directives. Through the full implementation of all the pillars of this regulation, 
commercial banks in Kosovo, through this regulatory framework, redefine regulatory capital and determine capital requirements against credit risk through the application of a standardized risk weighting approach to credit risk exposures, setting requirements for adapting credit risk mitigation techniques, as well as capital requirements for market and operational risk.

\section{References}

Apostolik, R., \& Donohue, C. (2015). Foundations of Financial Risk: An Overview of Financial Risk and Risk-based Financial Regulation (Wiley Finance)

Anjom, W., \& Karim, A. M. (2016). Relationship between non-performing loans and macroeconomic factors with bank specific factors. Asia Pacific Journals- ELK, VII(2).

Bokhari, H. I., \& Ali, M. S. (n.d.). Determinants of Capital Adequacy Ratio in Banking Sector:An empirical analysis from Pakistan. Academy of Contemporary Research Journal.

Klaasswn. P \& Eeghen .I. (2009). Economic Capital. In K. \&Eeghen.I, Economic Capital (pp. 18-26). USA.

Lipunga, A. M. (2014). Determinants of Profitability of Listed Commercial Banks in Developing Countries:Evidence from Malawi. Resarch Journal of Finance and Accounting, V.

Liu, S. (2013, August). Determinants of the profitability of the U.S banking industry during the financial crisis. TigerPrints.

Ozili, K. P. (2015, January). Determinant of Bank Profitability and Basel Capital Regulation: Empirical Evidence from Nigeria. MPRA- Munich Personal RePEc Archive.

Rengasamy, D. (2014). Impact of Loan Deposit Ratio on Profitability: Panel Evidence from Commercial Banks in Malaysia. Third International Conference on Global Business,Economics,Finance and Social Sciences (GB14Mumbai Conference).

Returns on Assets and Capital Adequacy of Banks in Nigeria. (2016, December 25). Advances in Social Sciences Research Journal, III.

Shmaki, D., Alulis, I. K., \& Sayari, K. (2016, May 25). Financial Information Influencing Commercial Banks Profitability. International Journal of Economics and Finance, VIII. 